\title{
Solar Resourses of Uzbekistan's Samarkand Region
}

ISSN: 2576-8840

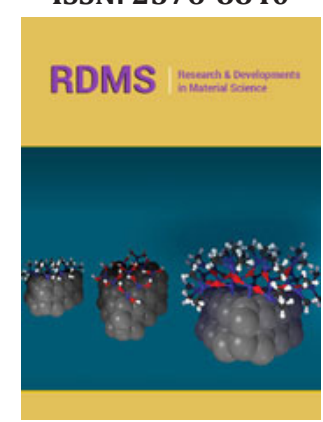

${ }^{* 1}$ Corresponding author: Yuldash Sobirov, Institute of Material science Scientific-Production Association PhysicsSun, Uzbekistan

Submission: 眥 March 23, 2019

Published: : March 27, 2019

Volume 10 - Issue 2

How to cite this article: Yuldash S, Shavkat F V. Solar Resourses of Uzbekistan's Samarkand Region. Res Dev Material Sci. 10(2).RDMS.000734.2019.

DOI: 10.31031/RDMS.2019.10.000734

Copyright@ Yuldash Sobirov, This article is distributed under the terms of the Creative Commons Attribution 4.0 International License, which permits unrestricted use and redistribution provided that the original author and source are credited.

\section{Yuldash Sobirov* and Shavkat Fayzie V}

Institute of Material science Scientific-Production Association, Uzbekistan

\section{Opinion}

In economically developed and developing countries there have being rapidly conducted works for the practical use of alternative energy sources, including solar energy, as a key factor of sustainable development and for increasing competitiveness of economies in conditions of reducing the world's hydrocarbon reserves. Thus, for example, researches in the sphere of using the solar energy in a number of countries are being conducted at the level of major national programs aimed for a long period.

Currently in Uzbekistan there being developed a draft of the law on development of alternative energy, as well as a number of legal documents in this sphere. The first major steps in the practical use of solar energy were initiated. In the Republic's six regions automatic weather stations measuring data collection on solar resources had been installed by CSP Services (Germany) company with the technical assistance of the Asian Development Bank (ADB). Five measuring stations were installed on meteorological plots of the Uzhydromet: Dagbit (Samarkand region), Karmana (Navoi region) Guzar (Kashkadarya region) Sherabad (Surkhandarya region), Pap (Namangan region), as well as on the territory of the NPO PhysicsSun in Parkent (Tashkent region) [1]. In these regions in the coming years it is planned to build five commercial and one solar energy station for demonstration.

In Samarkand region, there will start building of photovoltaic plant with capacity of 100MW. ADB experts also developed preliminary feasibility studies for the construction of $100 \mathrm{MW}$ of photovoltaic power plants in Guzar, Sherabad and Pap, integrated solar energy plant with the capacity of $130 \mathrm{MW}$ with combined cycle in Karman and demonstration solar thermal plant with capacity of 10MW in Tashkent region. Systematic measuring of solar radiation in Uzbekistan was launched more than sixty years ago in eight meteorological stations. However, since the early nineties actinometric observations in Uzbekistan were suspended. At the moment, as indicated above in Dagbit where previously conducted actinometry, in 2013 an automatic measuring station was installed. As previously noted, the new metering stations were set in relation to the construction site for their future solar power. Plots for construction of solar energy plants have been identified in accordance with the technical, social and environmental criteria for selection of the places accepted in international practice.

Firstly, solar radiation data submitted under the directory and satellite observations are processed and averaged over the long-term observations. RSP sensor measurement dataannual. Second, the data directory, calculated on the basis of measurements carried out Resolution: $6^{30}, 9^{30}, 12^{30}, 15^{30}, 18^{30}$, and calculations have been taken certain assumptions. According to Barashkova [2], the error data calculated by the solar resource measured in discrete mode is $\pm 10 \%$ or more.

Thirdly, it is known that the satellites transmitting weather information functioning at different heights, and also used solar sensors and spectrometers from different manufacturers. In this regard, data received from different satellites are also different from each other. During measurements from satellites reflected radiation from the underlying surface of the earth it is taken into account the dependence of the reflectance when the sun's rays passing between the earth and the satellite. Given that satellites carrying meteorological observations operate on different heights (geostationary height of $36,000 \mathrm{~km}$ polar orbit, $830 \mathrm{~km}$ altitude; 
solar-synchronized, the height of $800 \mathrm{~km})$, and also have different measurement tools, so the data on a sunny resource differ from each other, as can be seen from Figure 1. In this regard as basic solar data were taken yearly data, measured by the sensor RSP in conjunction with the satellite data.



Figure 1: Data on the solar resource produced by different satellites.

\section{References}

1. Lutpullaev SL (2015) On the measurement of solar resources in Uzbekistan.
2. Barashkova EP (1988) Actinometry, atmospheric optics and ozonometry. Trudy GGO them AI MGO, Issue 519, Leningrad, Russia.

\section{For possible submissions Click below:}

